\section{MR. AYRTON AND DR. HOOKER}

THE comments which have been made by several London journals upon the circumstances referred to in the subjoined memorial, seem, in the interest of all persons concerned, to render its publication in its entirety desirable. We cannot doubt that any delay which has occurred, or may occur, in the delivery of a reply to the memorialists, is due to the desire of the Prime Minister to deal with the important question at issue in a manner which, while it is not inconsistent with the interests of the public service, is not incompatible with a due regard for the interests of Science, and for fair dealing towards a very eminent scientific man.

\section{To the Right Hon. W. E. Gladstone,}

\section{First Lorit of the Treasury, Sic. Scc.}

We, the undersigned, deeply interested in the condition of English science, and viewing with special concern the treatment which the eminent Drrector of the botanical establishment at Kew has systematically received at the hands of Mr. Ayrton since his appointment to the office of First Commissioner of Works, do most respectfully beg your attention to the following statements and observations.

In the year I 840 the private Botanic Gardens of IKew, which had previously been in the possession of the Royal Family, were handed over by the Queen to the Government.

A commission then appointed to repurt on their condition re. commended that they should be enlarged and maintained as a national scientific establishment, which should form a centre of reception for the useful products of the vegetable kingdom, a centre of reference and distribution for England, India, and the colonies, and a means of augmenting the rational pleasure, increasing the knowledge, and refining the taste of the English public.

The late Sir William Hooker was at that time Prof. of Botany in the University of Glasgow. The founding of an estabiishment like that contemplated at Kew harmonised so completely with his scientific tastes and power of organisation, that, at a sacrifice of more than half his income, he offered to undertake the superintendence of $\mathrm{Kew}$ Gardens. His offer was accepted, and he was appointed Director of Kew, at a salary of $300 l$. a year.

Sir William Hooker was at that time the possessor of an excellent private herbarium and of a scientific library, both of which were wanting at Kew. To provide house-room for these an additional 200\%. was granted by the Government. No allowance, however, was made for the maintenance or increase of either the herbarium or the library. The expense of both fell upon the director.

During his residence in Glasgow, the excellence of his collections had attracted to the house of Sir William Hooker various active investigators, the number of which increased materially after his arrival at Kew. Fourteen rooms of the house he occupied were devoted to his herbarium, which for twelve years was the resort of the scientific botanists of Europe. Unaicled by the Government, save to the extent above mentioned, Sir William Hooker devoted his private means to the purchase of new books and specimens, and opened a corresponuence with botanists of all lands. He thus made his house the most extensive botanical laboratory in this country, and the most important centre of reference regarding systematic, economic, and descriptive botany, as illustrated by his herbarium.

The gardens expanded equally under his vigorous and enlightened supervision; in ten years after his appointment they became the first in the world.

For twenty-five years he had been collecting textile fabrics, drugs, gums, dyes, and other prodincts to illustrate the structure, uses, and physiognomy of plants. With these collections, made at his private cost, Sir William Hookex founded in Kew Gardens the first museum of the kind that had ever been established. Of such museums there are now three at Kew. They contain upwards of 50,000 named objects of scientific and economic interest, views of tropical vegetation, and maps illustrating the distribution of plants over the globe. These museums constitute concrete courses of instruction, unrivalled in concentration and completeness; and the public interest in them is proved by the number of persons who avail themselves of the stores of information thus provided.

The contributions of Sir William Hooker to these museums were his free gift to the country, for which he never received a farthing of remuneration.

In 1852 the director's salary, which haci previousiy been raised to $600 l$. a year, was augmented to $800 l$., together with a house which had become vacant at the time. The herbarium was then lodged in a separate building, and immediately afterwards donations and legacies (some to the director, some to the Government of the day) poured into it. The labour of naming the collections of expeditions, and of drawing up botanical reports, became at length so excessive that the public need of the herbarium was still further recognised by the Government. The director had previously borne the expense both of assistance and maintenance; of these he was now relieved, though he still continued to bear the cost of books for his library and of new specimens of plants.

Without this personal devotion on the part of the director, the development of Kew wuald have been a simple impossibility. For five-and-twenty years his purchases were made and his collections elaborated at his own expense and risk, though they were constantly employed in the work of the country. Before his death, knowing that his son could not afford to be as regardless of pecuniary considerations as he had been himself, he gave directions to have his herbarium valued by competent persons and offered to the Government at the lowest valuation. On these terms the coilections which had previously been devoted to the nation's use became the property of the nation itself.

This is a brief but sufficient statement of the relationship of Sir William Hooker to Kew Gardens. It shows him to have been their virtual creator.

The antecedents and achievements of the present Director of Kew may be thus sketched. In 1839 Dr. Joseph Hooker was appointed Assistant-Surgeon and Naturalist to the Antarctic Expedition, the most perilous, perhaps, that ever sailed from these shores, and the scientific results of which exceeded in importance those of any other naval exploring expedition of this ceniury. During this voyage Dr. Hooker recelved from the Government the pay of his rank as a medical officer. His outfit, his books, his instruments, were provided by his father. The expenses of travelling and collecting ashore during his four years' voyage of circumnavigation were defrayed from the same source, though this work was done with the express object of enriching a public establishment.

On his return, he waved his clain to promotion in the navy, and devoted four additional years to the classification and publication of the results of the voyage. He also aided his father as an unpaid volunteer in the development of the scientific branches of the Kew establishment.

In I847 Dr. Hooker was sent to India, to explore, in the interests of Kew, an unknown region of the Himalaya; and he was directed to proceed subsequently to Borneo, to report on its vegetable resources. His outfit, both for India and Borneo, which embraced a large collection of expensive instruments, cost the Government nothing. To cover all expenses incidental to his three years' travelling and collecting, including the cost of assistants and specimens, a sum of $1,200 \%$. was received, while the real disbursements of Dr. Hooker during this time amounted to $2,200 \%$. The difference was contributed by Sir William Hooker and his son, in the interest of the establishment to which they had consecrated their best energies.

On his return from India, Dr. Hooker again devoted himself to the work of aiding his father in the scientific development of Kew. He was also employed by the Admiralty, during the nine years from $185 \mathrm{I}$ to 1860 , in publishing the botanical discoveries of various naval and other voyages, from Captain Cook's downwards, to parts of the world visited by Dr. Hooker himself. For this service he received three years' pay as a medical officer in the Navy, together with a sum of $500 \%$, which was accompanied by "the expression of their Lordships' approbation of the zeal, perseverance, and scientific ability displayed in bringing to a successful completion this great botanical work." For three years he was occupied with the arrangement and distribution of his Indian collections, and with the publication of his journals. To cover the expenses incidental to these labours, an allowance of $400 l$. a year was granted by the Government.

Besides the voyages and travels above adverted to, Dr. Hooker has made journeys to various parts of Europe, to Western Asia, and to North Africa. The expenses of these journeys, though they were made with the express object of adding to the interest and completeness of Kew, have been borne by himself, and the results given to the establishment of which he is director.

We place these data before you, not with a view of founding on them either censure or complaint. The labours of $\mathrm{Dr}$. Hooker, 
and the heavy drain upon his father's purse which his unexampled education as a botanist involved, constituted the discipline which made him the man he now is. But we think it highly desirable that you and England should know as much of his career as will enable you to decide whether its arbitrary interruption by your First Commissioner be creditable to the Government of this country.

In 1855, Sir William Hooker being then seventy years of age, Dr. Hooker was appointed his Assistant-Director, at a salary of $400 \%$. a year, without a house; and from this time his share in the duties of the Garden were added to his more purely scientific ones. In $185^{8}$ his salary was increased to $500 \%$. a year, with a house, and in 1865 , on the death of his father, he succeeded to the Directorship without an assistant.

The liberality of his father and his own self-denying life in the public service have, we think, been sufficiently illustrated. We will therefore ask permission to place before you only one addi tional specimen of his conduct. As regards the Floras of Asia, Africa, and America, the Herbarium at Kew had been long unrivalled. Europe, however, was but scantily represented. Three years ago, a collection embracing the very fora needed for the completion of Kew was offered for sale in Paris. At his own private cost, Dr. Hooker purchased this collection for $400 l$., and presented it to the Kew Herbarium.

His income at Kew is 800 l. a year, and here is one-half of it voluntarily devoted to the establishment which it had been the continual object of his father and himself to raise to the highest possible perfection. Had these things been known to the Parliament and public of England, the First Commissioner of Works would, we imagine, have hardly ventured to inflict upon the Director of Kew the unnecessary toil, worry, indignity, and irredeemable loss of time against which this memorial is a remonstrance.

Under the auspices of his father and himself, Kew Gardens have expanded from 15 to 300 acres. They have long held the foremost rank in Europe. In no particular does England stand more conspicuously superior to all other countries than in the possession of Kew. The establishment is not only without a rival, but there is no approach to rivalry as regards the extent, importance, or scientific results of its operations. Upwards of I 30 volumes on all branches of botany, including a most important series of Colonial Floras, but excluding many weighty contributions to scientific societies and Journals, have been issued frum Kew. To these are to be added guide-books and official papers. This vast literature has been produced and published through the efforis of the directors of $\mathrm{Kew}$, for the most part at no expense whatever to the nation.

To these labours is to be added the correspondence of the directors with all parts of the world, a mere selection from which, now bound together at Kew, embraces some 40,000 letters addressed to the directors, and for the most part answered with their own hands.

Of the popularity of the Gardens, which has been attained without prejudice to their scientific use and reputation, it need only be stated that from 9,000 visitors in $184 \mathrm{I}$, the numbers have risen to an average of nearly 600,000 a year. What they have done towards the elevation and refinement of the tastes and conduct of the working classes may be inferred from the fact that last Whit Monday 37,795 visitors entered and quilted the Gardens without a single case of drunkenness, riot, theft, or mischief of any kind being reported.

Since Dr. Hooker's accession the Gardens have been to a great extent remodelled, and the establishment wholly reorganised. A great saving in outlay has thus been effected, without any sacrifice of efficiency. During the ten years from 1863 to 1872 inclusive, the annual number of living plants sent from Kew to various parts of the world has been doubled, amounting on an average to eight or nine thousand annually. Of seeds ripened at Kew, or obtained by the director from various parts of the world, the annual average distributed amounts to about seven thousand.

Of the practical value of these labours, the introduction of the Cinchona plant into India, Ceylon, and Jamaica, the commercial success of which is established, constitutes one of many illustrations. The introduction of Ipecacuanha is another. This will be corroborated by Her Majesty's Secretaries of State for India and the Colonies. We would add, that there is scarcely a horticultural establishment at home or abroad which would not be willing to acknowledge its indebtedness to Kew.

In India upwards of thirty gardeners trained at Kew are now employed in forestry, cotton, tea, and cinchona plantations,
Government gardens, \&c., and a far greater number are usefully employed in other parts of the world.

By the joint efforts of the directors, a series of complete Floras of India and the Colonies was set on foot at Kew, of which those of the West Indies, all the Australian Colonies, New Zealand, Tropical Africa, the Cape Colonies, and British India are completed or in progress. These are standard works of inestimable value in the countries whose plants they describe, as well as to scientific travellers and institutions in Europe.

We have hitherto confined ourselves to a statement of $\mathrm{Dr}$. Hooker's services in relation to Kew, and have said nothing of his labours in geology, meteorology, and other sciences, nor of his researches while Botanist of the Geological Survey. Durıng his single year of office he contributed to the Records of the Survey two memoirs, which are to be regarded as landmarks in the history of fossil botany. In presenting the Royal medal to Dr. Hooker in 1854, the president of the Royal Society spoke of these memoirs as " one of the most important contributions ever made to fossil botany." We may add a reference to his adven. turous explorations of the northern frontier of India, in regions never visited by a European before or since.

It is not likely that a rnan of these antecedents, accustomed to the respect which naturally follows merit of the most exalted kind, would in any way expose himself, and more especially in matters relating to the welfare of $\mathrm{Kew}$, to the just censure of his official superiors. Until the advent of the present First Commissioner, he had never been the object of a censure, and was never interfered with in the practical discharge of his duties by the Board of Works. His proposals and suggestions were rightly scrutinised, and his estimates regulated by the opinions of the Board, but the current duties were left entirely to his conduct and supervision; the extension and improvement of the establishment being always the origination and work of the Director.

With this sketch of the early training of Dr. Hooker for his present post before you, you will be able to compare with it the early training of Mr. Ayrton for the position which, by your favour, he occupies as Dr. Hooker's master. You will be able to judge how far the First Commissioner is justified in treating the Director of Kew with personal contumely, and in rudely upsetting the arrangements which he had made with reference to the invaluable collections for which he is responsible, not to $\mathrm{Mr}$. Ayrton alone, but to his conscience and his country.

Neither you, Sir, nor the English public have forgotten the speech of the First Commissioner on presenting himself for re. election at the Tower Hamlets, when he went out of his way to insult "architects, sculptors, and gardeners." That speech was a warning to every cultivated man who held office under the Board of Works, and it was, as you know, duly laid to heart by the Director of Kew. His desire to avoid all cause of offence was thus expressed in a letter addressed to yourself on August 3I, I87 I :- "Having regard to the tenor of the sentiments Mr. Ayrton is reported to have expressed in public on accepting office, $I$ felt it incumbent on me to be especially circumspect in my conduct and demeanour under his rule."

Circumspection, under the circumstances, was of small avail, and one of Mr. Ayrton's first acts, after taking office, was to send a reprimand to Dr. Hooker. It was a new experience to the Director of Kew. During his thirty years of public service such a thing had never once occurred; indeed, the very reverse of it had always occurred, the respect due to intellectual eminence and moral worth having been always cheerfully accorded to $\mathrm{Dr}$. Hooker by his official superiors. This first reprimand of his life was, moreover, not due to any fault of his, but arose entirely from the First Commissioner's own misconception.

The responsibility of the warming and ventilation of the planthouses had, by special order, devolved upon the Director. After a searching inquiry, Dr. Hooker had been entrusted by a previous First Commissioner with the task of remodelling the heating apparatus throughout the establishment; and this led to the construction at $\mathrm{Kew}$, in accordance with the Director's plans and estimates, of the most complete range of hot-houses for scientific purposes in existence. In $187 \mathrm{I}$, however, he accidentally dis. covered that he had been superseded in the duty, without notice given or reason assigned. He wrote a respectful letter of in quiry to the First Commissioner, and received the short-we are persuaded you will agree with us in adding, insolent-intimation that he had been superseded, and would have " to govern himself accordingly."

He would, in our opinion, have been equally unfaithful to the 
science of which he is a leader, and the public which he had so lony served, if he had bowed in silence to this rebuke. He wrote a second letter of remonstrance to the First Commissioner, in which he expressed himself as follows: "The matter, therefore, stands thus : Several months ago I was, unknown to myself, deposed from the discharge of a function of great importance. I was left to hear this accidentally and, I have now to add, through one of my own subordinates.

"I do not for a moment question the First Commissioner's power to exercise arbitrary authority over the Director of Kew, but I do submit that there has been bitherto no plea whatever for such action as regards myself, and that the repetition of such acts, and the leaving me to be informed of them, on each occa. sion, by my subordinate, constitute a grievous injury to $\mathrm{my}$ official position, and tend to the subversion of all discipline in this department."

At this point, Sir, Dr. Hooker turned in the fullest confidence to you. He had undoubting trust in your will and power to protect both Kew and him from the arbitrary and, we would add, jgnorant acts of the First Commissioner. He respectfully claimed the privilege of bringing the matter under the cognizance of the Right Honourable the First Lord of the Treasury.

You doubtless remember the letter addressed to you by Dr. Hooker on August 19, 1871. You could not fail to remark the reluctance with which he appealed to you, and his previous anxiety to take all possible measures to avert the necessity of such an appeal. "I cannot express to you, Sir," he writes, "thc anxiety that this step costs me, nor how earnestly I have endeavoured by suppressing all personal feelings, to conduct my duties here under $\mathrm{Mr}$. Ayrton to his and to my own satisfaction.

"After upwards of thirty-two years spent in the public service at home and abroad without a suspicion of mistrust on the part of my many previous superiors, I have had since Mr. Ayrton's accession to submit to various arbitrary measures, which, though compromising my position and authority, have been concealed from myself and become known to my subordinates, through whom alone I have first been made cognizant of them."

From you, Sir, the Director of Kew received no direct reply to this communication; but by the First Commissioner he was requested to "furnish the dates and particulars of the conspicuous profs of disregard to his office, and the particular occasions and facts with dates, of his being left to be informed through his subordinates of acts of arbitrary authority of the First Commissioner, and the dates and particulars of those acts."

To this challenge the Director of Kew replied by adducing five distinct acts of arbitrary interference, with their "dates," "proofs," and "particulars." * Among them was included what we have a right to call clandestine tampering with the subordinates at Kew. For example, the Curator of the Gardens was tempted by Mr. Ayrton, personally, to leave Kew by the offer of a higher position, involving authority over works at Kew ; and he was requested by Mr. Ayrton to keep the fact from the knowledge of Dr. Hooker. To the loyalty of this man to a master whom he trusted and loved, the Director of Kew owes the discovery of proceedings which under any previous First Commissioner would have been impossible.

Your attention, Sir, was drawn to this reply in a letter addréssed to you by the Director of Kew on the 3Ist of August, 187I. It is in every respect so excellent, and so sure to be appreciated by all who know the real meaning of scientific work, and the baneful effect upon such work of this harassing conflict with your First Commissioner, that we do not hesitate to reproduce it here in extenso.

"Royal Kew Gardens, August 31, I87I

"Sir,-I beg most respectfully to submit copies of my further correspondence with the Right Honourable the First Commissioner of Her Majesty's Works, \&c.

"The acts detailed in the accompanying letter are, I believe, correctly described. I trust that I do not exaggerate in charac terising them as grievously injurious to my official position, and tending to the subversion of discipline in this establishment; and I have evidently no protection from a repetition of them, except through the intervention of a higher authority.

"Of these acts, those referred to under $I, 2,3$, formed the subject of a prolonged correspondence between the First Com. missioner and myself; that under 4 , I brought to the notice of Mr. Stansfeld, and the result was the abandonment of the pro-

* Dr. Hooker's letter containing these charges was never answered, or event acknowledged, by Mr. Ayrton. posal ; that under 5 will, I venture to hope, be revoked by your authority. I refrain from commenting on these acts of the First Commissioner in reference to their seriously interfering with the execution of my peculiar and multifarious duties here.

"These include the labours of a Scientific Botanist, a Horticulturist, and the administration of Public Gardens, Museums, and Pleasure Grounds, frequented annually by upwards of 600,000 persons.

"Besides the living collections, I have the direction of the larsest and by far the most frequented Herbarium (by botanists and amateurs) in existence, and a very extensive Library.

"I conduct, wirhout a secretary, a responsible and cnerous correspondence with Foreign and Colonial Gardens, as also with the Admiralty and Indian and Colonial Offices, on all subjects connected with Horticulture, Forestry, Botany, and the appointment of officers to duties in connection with these matters, and the introduction of useful plants everywhere.

"I have, further, the editorship or control of various botanical works now being published, by order of Government, at Kew; and I have to devote every moment that I can spare from my duties to maintaining, by researches and publications of my own, a position as a Scientific Botanist.

"Until the accession of Mr. Ayrton, I have been enabled to fulfil these duties with satisfaction to myself, having been treated with uniform confidence, consideration, and courtesy by my superiors. I was invariably consulted on all prospective changes affecting my own and my subordinates' positions and duties. Or the revision of my estimates at the Board, before their trans mission to the Treasury, I was referred to ; and amongst my other current duties was the control of the construction and repairs of the hot-houses and heating apparatus throughout this establishment.

"Subsecuently to Mr. Ayrton's accession, my position has been materially changed in all these respects. He had hardly entered on his duties when he hastily administered to me a wholly unmerited reprimand (the first I ever received), and his last act (known to me) has been to take from me the abovementioned concrol, without pretext, warning, or subsequent intimation.

"I venture to hope that this may be restored to me, if the reasons I have adduced in tie enclosed letter to the First Com. missioner are satisfactory to you. To these 1 would add, that in all similar establishments with which $\mathrm{I}$ am acquainted, in England or abroad, the opinion of the cultivator is entitled to the first consideration in all matters relating to plant-houses and heating apparatus ; that to trust him with the care and treatment of invaluable collections, and make him amenable to the opinions of another in respect of the apparatus he requires, is as obviously wrong in principle as to refuse a surgeon his choice of instruments and hospital appliances. Nor would it be candid in me to withhold from you my conviction, that I have by this arbitrary act of the First Commissioner been lowered in the eyes of those who know no more of the circumstances than that I am deposed from the full control of buildings and apparatus which I was entrusted to erect and have still to use.

"Let me assure you, Sir, that I am unconscious of any feelings of personal animosity against Mr. Ayrton.

"Having regard to the tenour of the sentiments he is reported to have expressed in public, on accepting office, in respect of professional duties such as mine, $\dot{I}$ felt it incumbent on me to be especially circumspect in my conduct and demeanour under his rule. And in evidence of this let me add, that when still smart ing under his unprovoked reprimand, I, at his special request, devoted many nights to examining and reporting upon various books and pamphlets on the public parks of England, France, and America, for his guidance-a labour not very congenial and wholly beyond my province as Director of $\mathrm{Kew}$, and which I further undertook in the hope that it might lead the First Com. missioner to judge more generously of the acquirements and duties of some of the officers of the department he controls.

"I am, Sir

"Your most obedient Servant," "Jos. D. Hooker, Director

"To the Right Honourable The First Lord of the Treasury"

To this letter Dr. Hooker was honoured by a reply from yourself, couched in kind and considerate terms. You had communicated with Mr. Ayrton, and had received his explanations, which you forwarded to the Director of Kew, "in the hope that they would convey to his mind the assurance that there has been no 
intention on Mr. Ayrton's part to disregard his feelings or withhold the consideration due both to his person and his office."

Stress of public duty is quite sufficient to account for the fact of your overlooking the serious omissions and inaccuracies of the First Commissioner's "explanations." These, however, were immediately pointed out to you by Dr. Hooker. His object ia addressing you was not simply to complain of personal discourtesy on the part of the First Commissioner, but of five official acts subversive of discipline in the Kew establishment, and fraught with mischief to the public service. Had these acts merely affected him personally, he would have been perfectly willing to accept the assurance of Mr. Ayrton's consideration, though he failed to discover any trace of it either in his explauations or in the treatment which official papers sent from Kew continued to receive from the office of Works. He regarded it, however, as his duty, as an officer in the public service, to the Government and the scientific public, to spare no effurt to pro. cure a reversion of the policy introduced into the management of each and all of the departments of Kew (the Gardens, Museum, and Herbarium) by the present First Commissioner.

The specific acts enumerated by Dr. Hooker in answer to the request of the First Commissioner are thus summariset in a letter to yourself :-

"I. A transaction with my subordinate of a nature so new to my long experience of official life, and so repugnant to my principles, that I refrain from characterising it.

"2. Removing the Curator from his duties under me, without any communication with me.

"3. Empowering the Curator to act independently of me in regard to the times he should consider himselí under my orders, and instructing me to malke my arrangements in deference to his, and in concert with him.

"4. Submitting to the Treasury plans and estinates for extensive alterations in the Museum at Kew, without even informing me of his intentions; which works would have most seriously embarrassed me, as Director of the Museums, and would have involved a large expenditure, for which I believe no estimate was submitted, and which would have been in every respect detrimental.

"5. Superseding me, without previous or subsequent communication, in duties for the execution of which I held the Eoard's authority, and which I am of opinion should unquestionably be performed by the Director, i.e., the control of the heating apparatus of the hot-liouses, \&c."

In MII. A Arton's letter of "explanations," which you considered so satisfactory, the first three of these charges are skilfully ignored, and the other explanations contain statements which are demonstrably at variance with fact.

In the very considerate note above referred to, which was addressed by you from Balmoral to Dr. Hooker, you say: "There must be some mistake about Mr. Ayrton's failing to see you at Kew, as he assures me that he paid the visit there for the very purpose of personal and friendly communication."

We respectfully ask you to consicler how this "purpose" was carried out. Dr. Hooker was at home when the First Commissioner paid this visit to Kew. He omitted to inquire for the Director at his house, or at the Gardens, or of his subordinate, to whom Mr. Ayrton's visit was really paid. He held a conversation with this subordinate seriously compromising the Director's position and authority, which conversation he subsequently desired should not be communicated to the Director. The result of this conversation, moreover, was a communication to the Treasury affecting Kew, which was also kept from the knowledge of the Director. You will leam from these farts what the First Commissioner understands by "personal and friendly communication."

From its effects upon himself, Dr. Hooker could infer how disturbing the continual intrusion of this subject upon your attention must be. $\mathrm{He}$ was anxious to reduce this disturbance to a minimum, and therefore ventured to suggest that he should be put in communication with one of your private secretaries, to whom he might explain his position. To this request you, in the kindest manner, assented, and placed Mr. West in communication with the Director of Kew.

Sorely against his inclination, but driven to it by the necessities of the case, Dr. Hooker, at an interview with Mr. West on the 3oth of October, distinctly pointed out the grave errors and omissions contained in the "Explanations" given by the First Commissioner to the First Lord of the Treasury:

The end of the year approached without any answer being made to these communications and representations, and towards the close of December Dr. Hooker wrote again to Mr. West, who thereupon replied that a plan was under the consideration of the Government which would materially alter his position with reference to the First Commissioner of Works. He was subse. quently informed semi-officially that the scheme was maturing, and the hope was expressed that he would take no step likely to embarrass the Government. This was far from his wish or in. tention. But after waiting till the 2 Ist of Felbruary, the Director was semi-officially informed that the Government plan for his relief, and for the protection of Kew, had been abandoned.

In the hope of a satisfactory settlement, the matter was subse. quently placed by you in the hands of the Marquis of Ripon, and on the $13^{\text {th }}$ of Marci, 1872 , before a Committee of the Cabinet, consisting of the Mrarquis, Lord Halifax, and Mr. Cardwell, Dr. Hooker, by the desire of the Committee, handed in a memorandum containing a statement of the points wherein his relations to the Govermment required definition and correction.

The mpshot of these friendiy effurts was this: On the 15 th of April, 1872 , Lord Ripon was asked to convey the following verbal message from yourself to Dr. Hooker, which, the noble Marquis added, was to be regarded by the Director of Kew as a final answer to his appeal : "Mr. Ayrton has been told that Dr. Hooker should in all respects be treated as the head of the local establishment at Kew; of course in subordination to the First Commissioner of Works."

At this time the controversy had, unlappily, reached a pitch far too serious to be stilled by such a message. In a letter to your private secretary, written immediately subsequent to the interview on the 3 oth of October, Dr. Hooker put his case thus: "I am at a loss what to say as to my future position under a Minister whom I accuse of evasion, misrepresentation, and mis. statements in his communications to the First Minister of the Crown, whose conduct to myself I regard as ungracions and offensive, and whose acts I consicler to be injurious to the public service, and tending to the subversion of discipline. Granting," he continues, "that the functions of a Director are restored to me, how am I to ast when ordered to underiake works that in. volve wasteful expenditure, or are otherxise detrimental? should be thankful for Mr. Gladstone's instructions on this head."

With great deference, we submit that the verbal intimation conveyed from you to Lord Ripon, and from Lord Ripon, through Mr. Flelps, to $D_{i}$ : Hooker, by no means met the issues here raised by the Director of Kew. He had suffered from the secret tampering of the First Commissioner with his subordinates; he had successfully resisted extravagant and foolish proposals made by the same Minister, His duties and responsibilities as regards the varmiing of the plant-houses hall, to the imminent jeopardy of plants of the rarest value, been transferred, without notice or justification, to the Director of Works. Another class of duties had, in the sanue secret manner, been trans ferred to the Secretary of the Board of Works. Surely, Sir, your message througn Lord Ripon, to all intents and purposes, einpowered the First Commissioner to continue his course of studied indignity? Wrong upon wrong had been committed, which your answer left unredressed. No wonder that, notwitl?. standing his esteem and regard for you personally, and his respect for all anthority rightly exercised, the Director of Kew should be driven to address to you, on the 22nd of April, a letter containing the following remonstrance :-

"The fact is, that the Directorship of Kew, which was formerly subordinated to the First Commissioner alone, has been by $\mathrm{Mr}$. Ayrton officially subordinated to the Secretary of the Board and the Director of Works in London, and this surreptitiously, without fault found or notice of any kind given, the Director being left to discover his altered position as best he could : and the Director has further been subjected to a series of arbitrary and offensive measures on the First Commissioner's part, against which he could not defend himself. These measures being destructive of discipline, and injurious to this establishment, the Director felt it to be his duty to bring both their nature and consequences officially under your notice, and to seek from you that justice which (as he had been assured by the officers of the Treasury) could be obtained only through an official appeal to the Prime Minister.

"After eight months' interval, during which further arbitrary measures have been resorted to by the First Commissioner (and four of which were passed under the assurance that a measure for effectual relief was under consideration), the position of the 
Director of Kew is not better, but worse than when it was first brought under your notice; for within that period his views with regard to the scientific and other appointments in the establishment have been absolutely set at naught.

"These circumstances are well known to the Director's subordinates. They know that he has been virtually deprived of authority and responsibility, and that his official appeals have been unanswered, and his complaints ignored. The basis of all order and discipline in the establishment is thus sapped, and the position of the Director rendered so anomalous, that his desire and determination to uphold the interests of Science at Kew, strengthened as they are by the moral and material support guaranteed to him, hardly suffice to render that position endurable.

"Your own practical wisdom will enable you to judge whether such a state of things is to be remedied by the curt and vague announcement (and such you must allow me to call it) which you have been good enough to make me through Lord Ripon.

"I have the honour to be, \&c.

$$
\text { "(Signed) J. D. Hooker" }
$$

Your verbal announcement through the Marquis of Ripon was subsequently defined by Mr. West as a private and friendly communication; and your secretary proposed that, as an official answer would be sent to Dr. Hooker's official application, the letter from which the foregoing extract is made should be considered as non avenue. Dr. Hooker, however, had shown his letter to friends whose counsel he had sought in this matter, and he therefore pleaded that you ought to see that which had been seen by others. With regard to the character of the verbal communication, Dr. Hooker had been given distinctly to understand that it was official and fizal. He, however, cheerfully accepted the assurance of your secretary, and awaited the official reply. It came, and we hereby respectfully submit it to your calm interpretation.

"Treasury Chambers, April 25, 1872

"SIR,-I am directed by the Lords Commissioners of Her Majesty's Treasury to acquaint you that their Lordships have been in communication with the First Commissioner of Works as to the matters contained in the 'letter which you have addressed to the First Lord of the Treasury.

"Their Lordships find that there is no difference of opinion upon the question of your position, which may be briefly defined as that of head of the local establishment at Kew, of course in subordination to the First Commissioner, and they anticipate no difficulty in the future regulation of the relations of that important establishment to the office of the Board of Works, in which the duties and powers of management are vested by statute.

"The present form of estimate for Kew Gardens laid by their Lordships before the House of Commons cannot now be altered, but it will be acted upon, and will in future be framed, in accord. ance with this letter.

$$
\text { "I am, Sir, }
$$

"Your obedient Servant

"(Signed) Charles W. Stronge, Principal Clerk "Director of Royal Bolanic Gardens, Kew."

The concluding paragraph of this document, which is evidently the really important one, has been submitted to various persons accustomed to the language of official life, and we do not believe that a single one of them is sure of its meaning. Dr. Hooker, while willing to put the best construction upon it, thought it necessary to make a final inquiry, which was preceded by these remarks :

"I am most desirous of giving their Lordships no further trouble, and am, of course, prepared either cheerfully to submit to their decision, whenever it is clearly given, or to resign the office which I hold; but I am unable to find in your letter any judgment whatever upon the points contained in the accompanying Memorandum, which have all been submitted to the First Lord of the Treasury in my letters of August 19 and 3r, or to the Committee of the Cabinet which $I$ had the honour of attending on March I 3 at Lord Ripon's residence.

"I trust that their Lordships will observe, that in seeking their decision on these several questions, I am raising no superfluous difficulties, but that it is impossible for me to understand my position until it receives their Lordships' anthoritative definition in respect of the above matters.

$$
\text { "I am, Sir, }
$$

"Your obedient Servant,

"Charles W. Stronge, Esq."

\section{"MEMORANDUM}

“ I. Up to the date of the appointment of a Director of Works (under the Board of Works) in 1870, I was entrusted, by a special warrant of the Board, with the duty of preparing the estimates for the construction and repairs of the plant-houses, museums, and warming apparatus in this establishment. This warrant has been cancelled, without fault found, inquiry made, or intimation given, and the duty transferred to the Director of Works.

"Will you be good enough to inform me if it is their Lordships' decision that the powers conferred upon me by that warrant be restored to me?

"Previous to the accession of the present First Commissioner to office, I was consulted whenever changes were made in the estimates which it is my duty to submit to the Board, prior to their transmission to the Treasury.

"Am I to understand that hereafter the estimates will not be altered by the Board without giving me an opportunity of stating my views?

" 3 . I was entrusted with the custody and distribution to scientific bodies, \&c. of the copies of the first volume of the 'Flora of Tropical Africa,' a work the publication of which I am officially instructed to superintend at Kew. On the publication of the second volume, the undistributed copies of the first were withdrawn, without inquiry, from my custody, and sent, together with those of the second volume, to the stationery office for sale.

"Would you be so good as to state whether I am in future to be entrusted with the custody and distribution of scientific works of which I (the unpaid editor) an entrusted with the publication by the Board?

"4. Previous to the accession of the present First Commis. sioner to office, I was consulted in all cases of prospective changes in the position and duties of my subordinates, and in all cases of proposed works that might affect my duties and responsibilities.

"I shall be glad to know whether I am in future to be consulted in regard to such matters.

" 5. The Department of Works having been brought under the rules of the Civil Service Commissioners, all candidates for employment at Kew are liable to be chosen by open competi. tion, except in cases where the qualifications required "are wholly or in part professional, or not ordinarily to be acquired in the Civil Service,' as set forth in Clause VII. of the Commissioners' Rules. The present First Commissioner of Works refuses to allow me to take advantage of Clause VII. in cases both of purely botanical and horticultural appointments.

"Am I hereafter to be allowed to avail myself of this clause, when it is of importance to the public service that I should do so?

"6. The Director of Works having been given power to in. terfere in matters for which I am still in part responsible, I am anxious to know-

"Whether I am to consider myself subordinate to the Director of Works in such matters, and to submit to his control in respect of them.

"Kew, May I, 1872" " JoS. D. HOOKER

To this letter no answer has been received.

It but rarely falls in either with our duties or our desires to meddle in public questions; and not until we found Dr. Hooker maimed as regards his scientific usefelness-not until we saw the noble establishment of which he has hitherto been the living head in peril of losing services which it would be absolutely impos. sible to replace ; not, indeed, until we had observed a hesitation upon ycur part which we believe could only arise from lack of information--did the thought of interference in this controversy occur to us. Knowing how difficult it must be for one engrossed in the duties of jour high position to learn the real merits of a conflict like that originated by the First Commissioner of Works, we venture to hope that you will not look with disfavour on an attempt to place a clear and succinct statement of the case before you.

That statement invites you respectfully to decide whether Kew Gardens are or are not to lose the supervision of a man of whose scientific Jabours any nation might be proud ; in whom natural capacity for the post he occupies has been developed by a culture unexampled in variety and extent; a man honoured for his integrity, beloved for his courtesy and kindliness of heart; and who bas spent in the public service not only a stainless but an illustrious life. The resignation of Dr. Hooker under the cir- 
cumstances here set forth would, we declare, be a calamity to English science and a scandal to the English Government. With the power to avert this in your hands, we appeal to your justice to do so. The difficulty of removing the directorship of Kew from the Department of Works cannot surely be insuperable; or if it be, it must be possible to give such a position to the Director, and such definition to his duties, as shall in future shield him from the exercise of authority which has been so wantonly abused.

\section{Charles I,YelL \\ Charles DARWIN}

Grorge Ben'tham, Pres. Linn. Society

Henry Holland, Pres. Royal Institution

Grorge Burrows, Pres. Roy. Coll. of Physicians

GEORGR Busk, Pres. Roy, Coll. of Surgeons

H. C. Rawlinson, Pres. Roy. Geogr. Society JAMES PAgET

William SPOTTISWOODE

T. H. HUXLEY

JOHN TYNDALL

\section{PROFESSOR AGASSIZ'S SOUTH AMERICAN EXPEDITION}

\section{1.}

PROF. AGASSIZ'S Second Report to Prof. B. Peirce, Superintendent of the United States Coast Survey, dated U.S. steamer Hassler, Concepcion Bay, June $\mathbf{I}$, is given in the Now York Tribune of June 26 . The Report is of so great value and interest, that we reprint it entire :-

Since I sent my first report concerning erratics in the Southern Temperate Zone, I have been much engrossed with this subject, and have turned my attention chiefly that way, leaving to Pourtales the superintendence of the dredging, and to Steindachner and Blake the care of the zoological specimens.

On the eastern coast of Patagonia I had but little opportunity of adding to the information I had already obtained at Monte Video. It was not till we put into San Mathias Bay for some repairs that I could gather a few new facts. This bay is particularly interesting, because one can there compare the position of the tertiary beds in the cliffs bordering the Atlantic with that of similar beds in the cliffs along the northern shore of the bay. The southern exposure of the latter runs for nearly a hundred miles at about right angles with the sea coast. In both cases the outcrops of the beds are so nearly parallel with the surface of the sea, that whatever may have been their changes of level with reference to the ocean, they still retain the horizontal position in which they were deposited. It is of the utmost importance to remember this point when considering the distribution of the erratics over this part of the country with reference to the agency that may have transported them to their present resting-place. Among these tertiary deposits are wellmarked banks of colossal oysters of considerable extent, one of which coincides with the level of low water, while another stands at least twenty-five feet higher. The difference of level between these two great beds of oysters is so considerable as to suggest a subsistence of the sea bottom during the deposition of the tertiary beds. Higher up there are outer layers full of smaller fossils-some about ten, others about twenty feet above the second oyster-bed. The oyster-beds are perfectly parallel with one another, and separated by thin layers of clay and sand. And so, also, are the upper tertiary beds containing the smaller fossils. Among these, one bank consists almost entirely of large numbers of a species of Scutella with a single perforation in the posterior interambulacral area. This bank is particularly well marked. A bank of hard sand higher up is also conspicuous, and so is another of hard clay standing about 100 feet above the sea-line.

As we shall see hereafter, and as Darwin has already stated, these tertiary beds extend all over eastern Patagonia, including the Straits of Magellan as far as Sandy Point. In consequence of disintegration the harder beds form as many retreating shelves, like stairs, upon the slope of the shore bank. Wherever surface denudation has taken place these shelves give rise to terraces, stretching horizontally at various heights all over the plains of Patagonia. The scenery at Cliff End reminded me somewhat of Gay Head and its tertiary formation, except that the upper part of the Cliff consisted chiefly of sandy clays, alternating with which are two distinct horizontal beds of considerable thickness, formed entirely of pebbles, rather small and uniform in size. These pebbles vary from the dimensions of a pea or a hazel nut to that of the fist, or more; but there are no boulders or large fragments of rock among them. It is noteworthy that, while these pebbles alternate in regular stratification with the sandy clays in the upper part of the cliff, they also occur upon the shelves below. In the latter case, however, they form only superficial deposits, and do not penetrate with the beds on which they rest into the interior of the strata. It has occurred to me that similar superficial accumulations of pebbles upon the shelves bordering the bed of the Santa Cruz River may have been mistaken by Darwin for indications of successive upheavals. It is certain that there are no beaches here, marking successive steps of the upheaval of the country. What Darwin has considered as evidence of a gradual rise of the shore are the denuded surfaces of the horizontal tertiary deposits which everywhere form parallel terraces. As formyself, $I$ see here no evidence of upheaval except the level of the fossil beds of oysters and other fossils in the tertiary beds above the water, and the presence of fresh shells of living species upon and above the shore banks. 'These, however, only indicate that an upheaval has taken place since the deposition of the tertiaries, and while the shells now living already existed, without pointing to the rise by successive steps. Still less does it appear to me that the country has been submerged during the transposition of the erratics. Toward the west end of San Mathias Bay, at Port San Antonio, where extensive denudations have taken place in the very formations here described, these same pebbles occur again. But at Port San Antonio, instead of being well defined, continuous horizontal beds above the sea-level, they are shore pebbles, covering in a deep layer the whole extent of the beach, the inequality of which they follow. Their position here shows, beyond the possibility of doubt, that the whole set of beds above which they rest in regular stratification at Cliff End has been completely broken down and recently removed by the action of the sea, and the pebbles themselves thus brought to the sea level. Of course it follows that these pebbles have not been ground upon the modern beach, but upon an older foundation, corresponding at the time to the level at which the pebble beds now stand at Cliff End.

So far the facts. I am inclined to add, as an inference from subsequent observations made farther south, the relation of which to the facts above stated seem to me clear, that these pebbles have passed through the mill of a glacier's bottom before they were worked up by the floods into their present position in the beds of Cliff End and upon the beach of San Antonio ; and I do not see why the floods which formed these denudations could not as well have been the result of the melting of ice at the close of the glacial period, as the result of a change of level between land and sea, As soon as geologists have learned to appreciate the extent to which our globe has been covered and fashioned by ice, they may be less inclined to advocate changes of level between land and sea, wherever they meet with the evidence of the action of the water, especially where no marine remains of any kind mark the presence of the sea. As I have already said, the small and remarkably uniform size of the pebbles in Port San Antonio is particularly noticeable, and also the fact that none but hard rocks, indeed, only the very hardest kind of rocks, are represented among them.

(To be continued.)

CONTENTS

Economic ENTOMOLOGY ............... . 197

Origin and Degtiny of Man. . . . . . . . . . . . . . x98

Our Book Shely. . . . . . . . . . . . . . . . . . rg9

LeTTERS To THE EDitor:-

The Rigidity of the Earth and the Liquidity of Lavas.--Prof. $T$.

STERRY HUNT, F.R.S. . . . . . . . . . . 200

Fouling of the Nile--Rev. Canon Kingstey, F.L.S. . . 200

Volcanoes of Central France--HeNRY NorToN . . . . . . 200

The Wanderings of the Esquimaux.-Dr. JoHN RAE, F.R.G.S. 200

The Aurora of February 4.-H. C. Russell. . . . . . 202

The Zoological Statjon at Naples $\ldots . . . \quad . \quad 202$

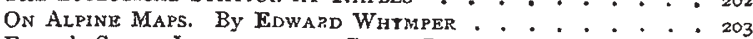
Evans's Stone Implements of Great Britain. I." (With Tlizs: trations). . . . . . BRITAN. I. (With Tlizs The Hunterian Museum . . . . . . . . . . 209 Notes . . . . . . . . . . . . . . . 200 Mr. AYrton AND Dr. Hooker . . . . . . . . . . . . $2 \mathrm{IL}$ Pror. Agassiz's South American Expedition, I. . . . . zit 